\title{
Resignation Syndrome Among Traumatized Children: A Brief Review on Latest Research Findings
}

\author{
Yolande Pigaiani ${ }^{1 *}$ and Anastasia Zocca ${ }^{2}$ \\ ${ }^{1}$ A.R.S.D.A. Association Research Study Alimentary Disorders, Italy \\ ${ }^{2}$ Indipendent Researcher, Italy
}

*Corresponding author: Y Pigaiani, A.R.S.D.A. Association Research Study Alimentary Disorders, 37122 Verona, Italy

\begin{tabular}{|c|c|}
\hline ARTICLE INFO & ABSTRACT \\
\hline $\begin{array}{l}\text { Received: 慧 June 05, } 2021 \\
\text { Published: 蔧 June 16, } 2021\end{array}$ & $\begin{array}{l}\text { Background and Objective: The resignation Syndrome has been investigated since } \\
\text { 1958. Despite the long time passed, there are still many questions about the pathogenesis } \\
\text { of this conditions. }\end{array}$ \\
\hline tation: Y Pigaiani, A Zocca. Resignatio & $\begin{array}{l}\text { Materials and Methods: Authors wrote a general review by examining the more } \\
\text { recent literature about Resignation Syndrome from Google Scholar website. }\end{array}$ \\
\hline $\begin{array}{l}\text { yndrome Among Traumatized Children: } \\
\text { A Brief Review on Latest Research Find- } \\
\text { ngs. Biomed J Sci \& Tech Res 36(4)-2021. }\end{array}$ & $\begin{array}{l}\text { Results: The main results report several hypotheses about causes of the resignation } \\
\text { syndrome which the main are learned helplessness, freezing reaction, sustained stress } \\
\text { response, traumatized mother's behavior and predictive coding framework. }\end{array}$ \\
\hline $\begin{array}{l}\text { Keywords: Resignation syndrome; Swe- } \\
\text { den; symptoms; hypothesis; Causes }\end{array}$ & $\begin{array}{l}\text { Conclusion: There is still much investigation to do about causes of resignation } \\
\text { syndrome. Future research should focus their interest in developing an exhaustive } \\
\text { multifactorial model and screening surveys to prevent this condition. }\end{array}$ \\
\hline
\end{tabular}

\section{Introduction}

Recently, the international community had focused its attention on a particular syndrome which affects specific ethnical minorities and seems to be more concentrated in Sweden. This particular condition has been called "Resignation Syndrome" and can be considered an extreme somatic and dissociative reaction to the risk of re-exposure to a traumatic event or to returning to a traumatic place [1]: main symptoms include reduced communication, motor skills and ability to carry out daily routines, catatonic stupor, coma, mutism, sleeping problems, depressive mood, withdrawal, loss of appetite, inability to ingest, weakness of the legs, and irritability [2]. In addition, secondary symptoms may appear, such as tachycardia, rise in temperature, weight gain, oedema, profuse sweating, reactivation of latent viral infection, skin ulcers and muscular atrophy. The typical discourse of the syndrome starts with a prodromal anxiousness and depressive symptoms such as lethargy and evolves into a stupor condition until provoking lack of any response behavior (even to painful stimuli) and apparent unconsciousness, making necessary tube feeding life sustaining. Remission takes from several months to years and implies a gradual return to normal vital functions [3].
The Resignation Syndrome has already been described in 1958 by the Swedish child and adolescent psychiatrist Anna-Lisa Annell [2] and on January 1st, 2014, the Swedish National Board of Health and Welfare recognized the novel diagnostic entity resignation syndrome. Nevertheless, the appropriateness of the diagnosis still has to be demonstrated, since it implies a psychological etiology. Nowadays, universal diagnostic criteria are still undetermined and there's lack of precise pathogenesis and effective guidelines for treatment [3]. According to Santiago, et al. [4] all cases of Resignation Syndrome have been registred in Sweden and the largest part of the patients that suffer from this desease had already been lived in the country for several years, while In Australia there have been reports of several refugee and asylum-seeking children with a syndrome very similar to the resignation syndrome among those who had been on the Island Nauru for several years [2]. Despite this finding, the regional distribution is still unexplained [3]. Since we still know little about the Resignation Syndrome, the aims of this study were:

a) To highlight risk factors which can lead to the development of the resignation syndrome. 
b) To provide theorical explanations about the causes of the resignation syndrome.

c) To discuss areas on which further research could focus to understand better the resignation syndrome.

\section{Materials and Methods}

Authors performed a manual research on Google Scholar to identify the most relevant studies about symptoms, risk factors and causes of Resignation Syndrome. The search terms that were used were "resignation syndrome", "adolescents", "children" and "Sweden". Only publications in English and Spanish were selected and thematically organized. The authors described the most major findings about the Resignation Syndrome and provided final indications for future research to the above.

\section{Results}

The main risk factors which lead to development of Resignation Syndrome are exposure to life threatening traumas such as physical abuse, harassment or by witnessing violence [3]. Another key factor is the personal and family's history of mental health illness, such as depressive disorder or PTSD [2]. Nonetheless many researchers suggest a multifactorial explanatory model involving psychological and or physical trauma, individual vulnerability, traumatization, migration, culturally conditioned reaction patterns, helplessness and hopelessness, familial expectations and obligations, the predicaments of migration and asylum seeking, including negative expectations regarding chances of obtaining a visa, parental dysfunction or pathological adaption to a caregiver's expectations to interplay in Resignation Syndrome pathogenesis [3].

\section{Discussion}

Many authors tried to detect an exhaustive explanation to highlight undergoing mechanisms of the Resignation Syndrome. Some of the main hypotheses are those involving concepts of learned helplessness, freezing reaction, sustained stress response, traumatized mother's behavior and predictive coding framework. The learned helplessness refers to a behavioral pattern in which a subject that believes that all hope of safety is lost reaches a catatonic state, while the freezing reaction is a fainting condition that involves the old part of the vagus nerve [2]. While the sustained stress response hypothesis argues that a stressor caused by the durable discrepancy between what is expected and what really exists could lead in some predisposed individuals to a severe reaction.

In addition, a psychoanalytic hypothesis has been described: Bodegård proposed that severely traumatized mothers have a typical attitude according to a specific coping strategy, in which the need of consolation is projected onto his child, creating a delusive fantasy of a dying child. Traumatized mothers are Infact characterized by a lack of trust, rejection of medical information excluding physical illness as causing the condition and resistance to rehabilitation and treatment on the child's behalf. The Resignation Syndrome develops in the child because the prospect of rejection by his or her mother is more frightening on a subconscious level than the reincarnation of the mother's delusive fantasy (that is the dead child).

Finally, the predictive coding framework theory argues that contextual factors create negative expectations which drives homeostatic and behavioral effects toward minimization of prediction error, even if this means pushing the physiological, cognitive and emotional state through a catatonia condition (that is the resignation syndrome state) in order to elicit support from the surrounding. Thus, homeostatic mechanisms are directed topdown to act specific goal directed behaviors, according to culturally sanctioned expectations of what that behavior entails [3]. To conclude, future research should consider investigating more deeply the risk factors of Resignation Syndrome, since we still don't undestand many aspects of its pathogenesis. Authors should also focus on the development of screening surveys and questionnaires to prevent the development of the syndrome in children, which could be proposed to families inside school environments and other institutions (hospitals, communities and clinics).

\section{Funding}

This research did not receive any specific grant from funding agencies in the public, commercial, or not-for-profit sectors.

\section{Acknowledgment}

The authors declare no acknowledgements.

\section{References}

1. Sánchez TS (2020) Resignation syndrome migratory trauma, somatization and extreme dissociation. Aperturas psicoanalíticas: Revista de psicoanálisis (63): 2.

2. Von Knorring AL, Hultcrantz E (2020) Asylum-seeking children with resignation syndrome: catatonia or traumatic withdrawal syndrome? European child \& adolescent psychiatry 29(4): 1103-1109.

3. Sallin K, Lagercrantz H, Evers K, Engström I, Hjern A, et al. (2016) Resignation syndrome: catatonia? Culture-bound?. Frontiers in Behavioral Neuroscience (10)7.

4. Santiago ISD, Freitas Neta MSBD, de Barros JCD, Landim JMM, Arrais TMSN, et al. (2019) Resignation syndrome in hidden tears and silences. International Journal of Social Psychiatry 65(1). 
ISSN: 2574-1241

DOI: 10.26717 /BJSTR.2021.36.005870

Y Pigaiani. Biomed J Sci \& Tech Res

(C) (P) This work is licensed under Creative

Submission Link: https://biomedres.us/submit-manuscript.php

$\begin{array}{ll}\text { BIOMEDICAL } & \text { Assets of Publishing with us } \\ \text { RESEARCHES } & \text { - Global archiving of articles } \\ & \text { - Immediate, unrestricted online access } \\ & \text { - Rigorous Peer Review Process } \\ & \text { - Anthors Retain Copyrights }\end{array}$

